\title{
Persistence of low back/pelvic girdle pains in women after pregnancy: An experience from Aminu Kano Teaching Hospital, Nigeria
}

\author{
Ayyuba Rabiu, ${ }^{1}$ Mustapha Ibrahim Usman, ${ }^{2}$ Muhammad Kabir Abubakar, ${ }^{2}$ \\ Sulaiman Muhammad Daneji, ${ }^{1}$ Ibrahim Garba, ${ }_{1}^{1}$ Shamsuddeen Muhammad, ${ }^{2}$ \\ Idris Sulaiman Abubakar ${ }^{1}$
}

${ }^{1}$ Department of Obstetrics and Gynecology, and ${ }^{2}$ Department of Surgery, Bayero University Kano/Aminu Kano Teaching Hospital, Kano, Nigeria

\begin{abstract}
Persistence of symptoms of low back pains and pelvic girdle pains are frequent complaints after pregnancy. Knowledge of back pain prevention and back education is essential for prevention and relief of persistence pains after delivery. The aim is to determine the factors that are associated with persistence of low back/girdle pains after pregnancy, the severity of the pains and measures undertaken by the patients for alleviation of this chronic condition. The study was a cross sectional survey. Ethics approval was obtained from Aminu Kano Teaching Hospital Ethics Committee. Information such as socio demographic characteristics of the clients, persistence and severity of low back pains/pelvic girdle pains after pregnancy and associated risk factors, was asked and documented on a questionnaire. Consecutive, consenting clients were recruited for the survey. Data collected were analyzed using SPSS Version 19. Qualitative data were summarized using frequencies and percentages. $\chi^{2}$ and Fishers' Exact tests were used, where appropriate, for categorical data. A $P$ value of $\leq 0.05$ was considered significant. During the period, 51 patients with chronic
\end{abstract}

Correspondence: Ayyuba Rabiu, Department of Obstetrics and Gynecology, Bayero University Kano/Aminu Kano Teaching Hospital, P.M.B. 3011, Nigeria.

Tel.: 08055559473

E-mail: ayyubarabiu@yahoo.com

Key words: Low back/Pelvic Girdle Pains, Persistence, After Pregnancy, Nigeria

Contributions: The authors contributed equally.

Conflict of interest: The authors declare no potential conflict of interest.

Funding: None.

Received for publication: 7 October 2019.

Revision received: 28 January 2020.

Accepted for publication: 30 January 2020.

This work is licensed under a Creative Commons Attribution NonCommercial 4.0 License (CC BY-NC 4.0).

(C) Copyright: the Author(s), 2019

Licensee PAGEPress, Italy

Annals of African Medical Research 2019; 2:90

doi:10.4081/aamr.2019.90 back/pelvic girdle pains or both were recruited. Their mean age $( \pm \mathrm{SD})$ was $30.9 \pm 5.62$ years. Bed rest was the most means of relief of low back/pelvic girdle pains. Variables such as advancing age, ethnic group, high parity, educational status and obesity were found to be present and high among patients with persistence of low back/pelvic girdle pains. However, only their employment status was found to be associated with the severity of their pains $\left(\chi^{2}=11.443, \mathrm{P}=0.001\right)$. The survey showed only employment status was statistically associated with severity of the low back/pelvic girdle pains $\left(\chi^{2}=11.443, \mathrm{P}=0.001\right)$. Other variables were not associated. There was low knowledge of back pain prevention and back education among the study group.

\section{Introduction}

Low back pain (LBP) and pelvic girdle pain (PGP) are frequent problems affecting pregnant women starting even in the early stages of pregnancy. They are very common problems among black population. A figure of $34.3 \%$ and $57.6 \%$ of LBP and PGP respectively was reported in North Western Nigeria. ${ }^{1}$ Persistence of symptoms of low back pains and pelvic girdle pains are frequent complaints after pregnancy. The incidence of persistent low back pains after pregnancy varied from the disappearance of pain in over $60 \%$ within 2 days after delivery, ${ }^{2}$ to as high as $82 \%$ having persistent pain at 18 months. ${ }^{3}$ Women with a combined low back pain and pelvic girdle pain recover to a lower degree (33\%) compared with those with only pelvic girdle pain $(66 \%)$ or low back pain $(72 \%)$ after delivery. ${ }^{4}$

It has been documented that low endurance of back flexors, older age, combined pain in early and work dissatisfaction are among several predictors of persistent low back pain after pregnancy. ${ }^{4}$ Predictors of poor outcome postpartum are previous low back pain, high pain levels postpartum, high BMI, high maternal age, physically strenuous work situation and low job satisfaction. There is an increased likelihood of poorer health in women with continuous pain postpartum. ${ }^{5-7}$ Studies on low back pain in the general population show previous reported sick leave and episodes of low back pain are predictors of poor outcome, persistence of symptoms and delayed recovery rate. ${ }^{7,8}$ Other potential risk factors known to influence poor outcome include age, marital status, duration of symptoms, psychological stress, low levels of physical activity, heavy physical work, high BMI and level of education. ${ }^{7}$ In addition, individual coping strategies are considered important contributors to future disability in regards to low back pain and psychosocial factors appear to exacerbate the clinical component of pain. ${ }^{9}$

The most effective non-surgical form of treatment is physiotherapy though a systematic review investigating the effectiveness 
of physiotherapy in women with low back pain is inconclusive. ${ }^{10}$ Clinicians need to realize that low back pain may not be transient for some women; instead some will become chronic in nature. Also that pregnant women need to be educated on risk factors, screened early in pregnancy and after childbirth, so as to facilitate early customized treatment or intervention, consequently decreasing the risk of transitioning into chronicity. ${ }^{8}$

This study was aimed at determining the factors that are associated with persistence of low back/girdle pains after pregnancy, the severity of the pains and measures undertaken by the patients for alleviation of this chronic condition among black population.

Table 1. Socio-demographic characteristics of the patients.

\begin{tabular}{|c|c|c|}
\hline Variable & Frequency & Percent \\
\hline $\begin{array}{l}\text { Parity } \\
\text { Primipara } \\
\text { Multipara } \\
\text { Grandmultipara } \\
\text { Total }\end{array}$ & $\begin{array}{c}16 \\
28 \\
7 \\
51\end{array}$ & $\begin{array}{c}31.4 \\
54.9 \\
13.7 \\
100.0\end{array}$ \\
\hline $\begin{array}{c}\text { Age Group } \\
20-24 \\
25-29 \\
30-34 \\
35-39 \\
40-44 \\
\text { Total } \\
\end{array}$ & $\begin{array}{c}9 \\
8 \\
17 \\
16 \\
1 \\
51\end{array}$ & $\begin{array}{c}17.6 \\
15.7 \\
33.3 \\
31.4 \\
2.0 \\
100.0 \\
\end{array}$ \\
\hline $\begin{array}{l}\text { Ethnic Group } \\
\text { Hausa/Fulani } \\
\text { Igbo } \\
\text { Yoruba } \\
\text { Other (Kanuri) } \\
\text { Total }\end{array}$ & $\begin{array}{c}29 \\
11 \\
10 \\
1 \\
51\end{array}$ & $\begin{array}{c}56.9 \\
21.6 \\
19.6 \\
2.0 \\
100.0\end{array}$ \\
\hline $\begin{array}{l}\text { Marital Status } \\
\text { Single } \\
\text { Married } \\
\text { Total } \\
\end{array}$ & $\begin{array}{c}3 \\
48 \\
51 \\
\end{array}$ & $\begin{array}{c}5.9 \\
94.1 \\
100.0\end{array}$ \\
\hline $\begin{array}{l}\text { Marriage Setting } \\
\text { Monogamy } \\
\text { Polygamy } \\
\text { Total }\end{array}$ & $\begin{array}{c}42 \\
9 \\
51\end{array}$ & $\begin{array}{c}82.3 \\
17.7 \\
100.0\end{array}$ \\
\hline $\begin{array}{l}\text { Order of Marriage } \\
\text { First Order } \\
\text { Second Order } \\
\text { Total }\end{array}$ & $\begin{array}{c}47 \\
4 \\
51\end{array}$ & $\begin{array}{c}92.2 \\
7.8 \\
100.0\end{array}$ \\
\hline $\begin{array}{l}\text { Religion } \\
\text { Islam } \\
\text { Christianity } \\
\text { Traditional } \\
\text { Total }\end{array}$ & $\begin{array}{c}32 \\
12 \\
7 \\
51\end{array}$ & $\begin{array}{c}62.8 \\
23.5 \\
13.7 \\
100.0\end{array}$ \\
\hline $\begin{array}{l}\text { Educational Status } \\
\text { Primary } \\
\text { Secondary } \\
\text { Tertiary } \\
\text { Total }\end{array}$ & $\begin{array}{c}4 \\
5 \\
42 \\
51\end{array}$ & $\begin{array}{c}7.8 \\
9.8 \\
82.4 \\
100.0\end{array}$ \\
\hline $\begin{array}{l}\text { Occupation } \\
\text { Home Managers } \\
\text { Business } \\
\text { Professional/Executive } \\
\text { Total } \\
\end{array}$ & $\begin{array}{l}20 \\
14 \\
17 \\
51 \\
\end{array}$ & $\begin{array}{c}39.2 \\
27.5 \\
33.3 \\
100.0 \\
\end{array}$ \\
\hline
\end{tabular}

\section{Materials and Methods}

The study was a cross sectional survey that was carried out in the department of obstetrics and gynecology of Aminu Kano Teaching hospital from $1^{\text {st }}$ January to $30^{\text {th }}$ June, 2019. Ethics approval was obtained from Aminu Kano Teaching Hospital Ethics Committee. Participation in the study was voluntary. Information such as socio demographic characteristics of the clients, persistence and severity of low back pains/pelvic girdle pains after pregnancy and associated risk factors, was asked and documented on a pre-tested closed and open-ended questionnaire by trained research assistants. Consecutive, consenting clients were recruited for the survey. Clients below the age of 16 years (difficulty in obtaining assent), were excluded from the study.

Data collected were analyzed using statistical package for the social sciences (SPSS) software package Version 19 (SPSS Inc, IL, Chicago, USA). Qualitative data were summarized using frequencies and percentages. A $\chi^{2}$ and Fishers' Exact tests were used, where appropriate, for categorical data. A $P$ value of $\leq 0.05$ was considered significant.

In this survey, chronic low back pain was defined as pain that persists for 12 weeks or longer, even after an initial injury or underlying cause of acute low back pain has been treated.

\section{Results}

The survey was carried out from $1^{\text {st }}$ January to $30^{\text {th }}$ June, 2019. During the period, 51 patients with chronic back pain, pelvic girdle pain or both were recruited. Their mean age $( \pm \mathrm{SD})$ was $30.9 \pm 5.62$ years. Their median age was 33.0 years. Their age ranged from 20 to 42 years. Their median parity was 2 . The average number of weeks after delivery was $4.6 \pm 1.62$ with a range of 3 to 13 weeks.

Table 1 shows the socio-demographic characteristics of the patients. Majority of them were multiparous women 28 (54.9\%); primipara were $16(31.4 \%)$. Age group of $30-34$ years was the majority $17(33.3 \%)$, followed by $35-39$ years $16(31.4 \%)$. The least age group was 40-44 years $1(2.0 \%)$. More than half of the patients were Hausa/Fulani 29 (56.9\%); the Igbos and Yoruba constituted $11(21.6 \%)$ and $10(19.6 \%)$ respectively. Almost all the patients were married $48(94.1 \%)$, in the first order of marriage 47 $(92.2 \%)$ and in a monogamous setting $42(82.3 \%)$. More than half

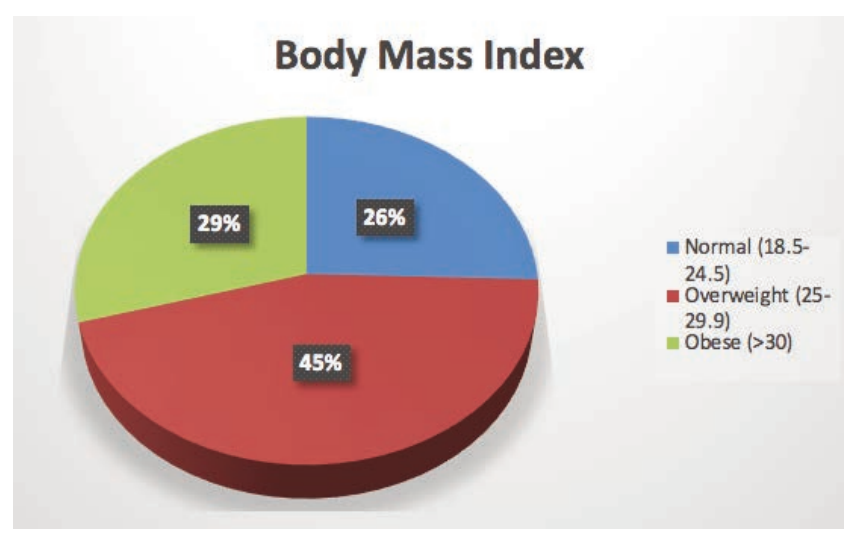

Figure 1. Body Mass Index of the Patients $\left(\mathrm{kg} / \mathrm{m}^{2}\right)$. 
of the patients were of Islamic faith $32(62.8 \%)$, the Christians constituted $12(13.7 \%)$.

A significant proportion of the patients attained tertiary level of education $42(82.4 \%)$; those with secondary and primary level of education were $5(9.8 \%)$ and $4(7.8 \%)$ respectively. Only 14 (27.5\%) were businesswomen, while 20 (39.2\%) and 17 (33.3\%) were housewives and professionals/executives respectively.

The mean weight $( \pm \mathrm{SD})$ of the patients was $74.5 \pm 10.36 \mathrm{~kg}$, their mean height $( \pm \mathrm{SD})$ was $164.0 \pm 12.03 \mathrm{~cm}$ and their mean age $( \pm \mathrm{SD})$ at first delivery was $27.0 \pm 5.36$ years. Their average BMI (body mass index) was $28.0 \pm 5.01 \mathrm{~kg} / \mathrm{m}^{2}$. Figure 1 depicts the BMI of the patients. All the patients currently presented with both low back pain and pelvic girdle pain following their last pregnancy and delivery. The average age ( \pm SD) of their last pregnancy at delivery was $30.6 \pm 5.71$ weeks, the average duration of their last labor was $5.4 \pm 3.81$ hours and the average weight of their babies was

\section{$2.9 \pm 0.55$ (Table 2).}

Table 2 depicts the symptomatology of low back/pelvic girdle pains. Only $8(15.7 \%)$ patients started experiencing low back/pelvic girdle pains during the first trimester of pregnancy; 20 $(39.2 \%)$ and $23(45.1 \%)$ started experiencing the pains since from the second and third trimester respectively. More than half of the patients were experiencing low back pains $28(54.9 \%)$ at the time of the interview. Only $17(33.3 \%)$ of the patients were employed, and up to $48(94.1 \%)$ delivered the last pregnancy before term. Spontaneous vaginal delivery was the mode of delivery in most of the patients 32 (62.8\%); however, $15(29.4 \%)$ were delivered via Caesarean section. Few of the patients 2 (3.9\%) labored for more than 12 hours during vaginal delivery and delivered macrosomic babies respectively.

There was antecedent history of low back pains 21 (41.2\%), pelvic girdle pains $3(5.9 \%)$ and both pelvic girdle and low back

Table 2. Symptomatology of low back/pelvic girdle pains.

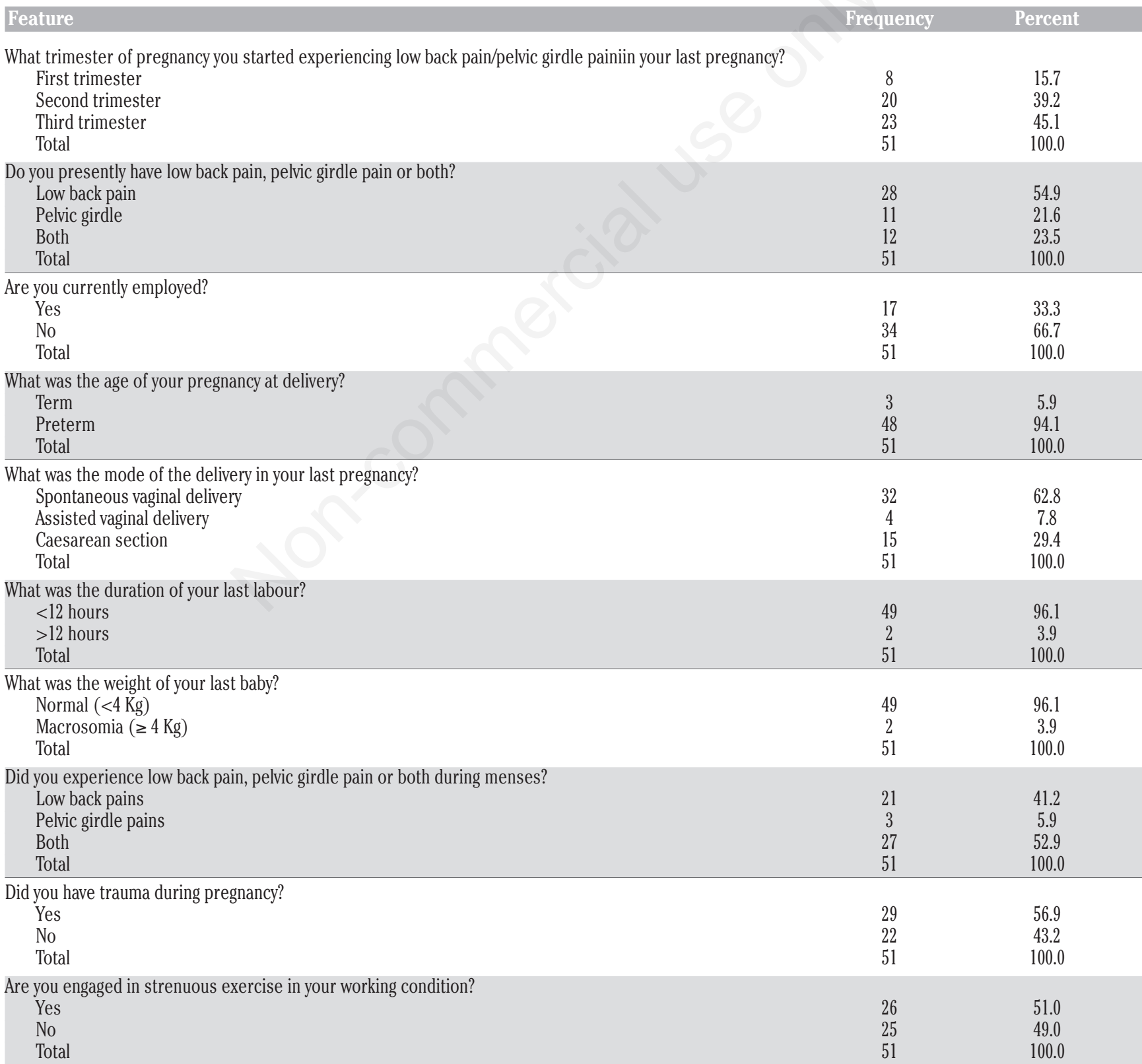


pains among the patients during menses. So also, 29 (56.9\%) of the patients admitted having trauma during pregnancy. Similarly, 26 $(51.0 \%)$ admitted having strenuous exercise at their working place.

Table 3 shows the nature of the pains experienced by these patients. The pain was described as burning 23 (45.1\%), dull 21 (41.1\%), and piercing $6(11.8 \%)$ by most of the patients. It radiates in about half of the patients $24(47.1 \%)$, with numbness 47 $(92.2 \%)$. Many of the patients with low back/pelvic girdle pains 42
$(82.4 \%)$ used to taking medication. It also prevented them from normal duties $26(51.0 \%)$, and in some, the pain was severe enough to warrant hospitalization 28 (54.9\%). Some mention family history of low back/pelvic girdle pains 19 (37.3\%).

Table 4 reveals the relationship between low back pain to work and back education. Only 20 (39.2\%) of the patients thought their pain was related to the kind of activities they do at work. They admitted that their work within the last two years involves sitting

Table 3. Nature of the pains.

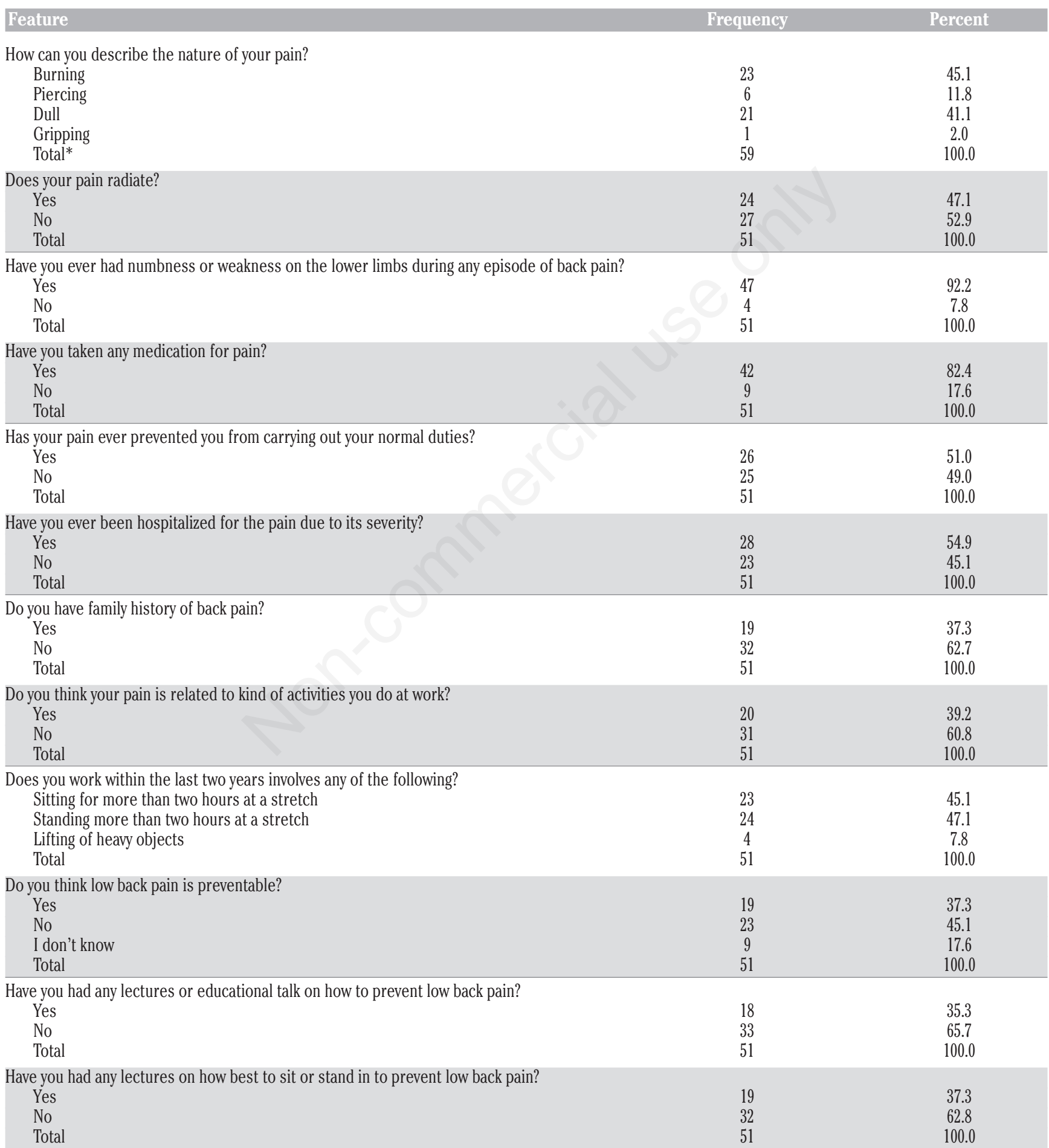

*Response not mutually exclusive. 
for more than two hours at a stretch, standing for more than two hours at a stretch and lifting of heavy objects in 23 (45.1\%), 24 $(47.1 \%)$ and $4(7.8 \%)$ respectively. Only $19(37.3 \%)$ thought low back pain was preventable and $18(35.3 \%)$ had any lectures or educational talk on how to prevent low back pains. Surprisingly, 19 $(37.3 \%)$ had any lectures on how best to sit or stand to prevent low back pain. Figure 2 shows where the pain radiates. In most of the cases, it radiated to the feet, followed by legs, upper back and thigh. Figure 3 shows the means of relief for low back pains among the patients. Bed rest was the most followed by medication and physiotherapy. Figure 1 depicts the body mass index (BMI) of the patients. Only $26 \%$ had normal BMI; $45 \%$ were overweight while $29 \%$ were obese. There was no statistically significant association between severity of the pains (evidenced by hospital admission) and their age groups ( $\mathrm{P}($ Fischer's $=)$ 0.723), parity $(\mathrm{P}($ Fischer's $=)$ 1.000), ethnicity ( $P$ (Fischer's $=)$ 0.297), marital status ( $P$ (Fischer's=0.242), marriage setting ( $\mathrm{P}($ Fischer's $=)$ 0.487), order of marriage ( $\mathrm{P}($ Fischer's $=)$ 0.617), religion ( $\mathrm{P}($ Fischer's $=)$ 1.000), educational status ( $\mathrm{P}($ Fischer's $=)$ 0.561) or occupation $\left(\chi^{2}=4.806\right.$, $\mathrm{P}=0.101$. Also, there was no statistically significant association between the severity of the pains and their BMI $\left(\chi^{2}=6.122\right.$, $\mathrm{P}=0.056$ ) or the trimester of pregnancy pain started ( $\mathrm{P}$ (Fischer's $=$ ) 0.932). However, there was statistically significant association between their employment status and the severity of their pains $\left(\chi^{2}=11.443, \mathrm{P}=0.001\right)$. The employed were more likely to have hospital admission due to severity of the pains. Similarly, there was no statistically significant association between the severity of the pains and the gestational age at delivery ( $\mathrm{P}($ Fischer's=) 1.000), the mode of delivery ( $\mathrm{P}($ Fischer's $=)$ 0.556), the duration of the last delivery ( $\mathrm{P}($ Fischer's $=) 1.000)$, the weight of the baby in their last delivery (P (Fischer's $=)$ 1.000), antecedent history of trauma $(\mathrm{P}$ (Fischer's $=$ ) 0.581 ) or engagement in strenuous exercise $\left(\chi^{2}=2.354, \mathrm{P}=0.164\right)$.

Family history of low back pains was also not associated with the severity of the pains $\left(\chi^{2}=0.834, \mathrm{P}=0.398\right)$ (Table 5).

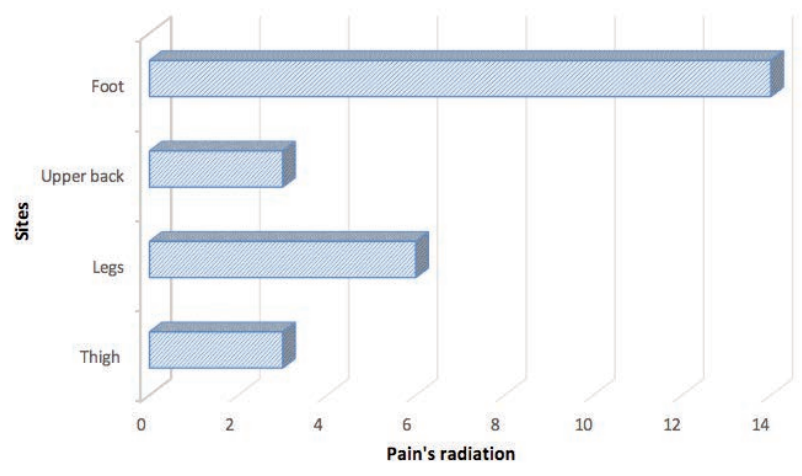

Figure 2. Sites of Pain's Radiation.

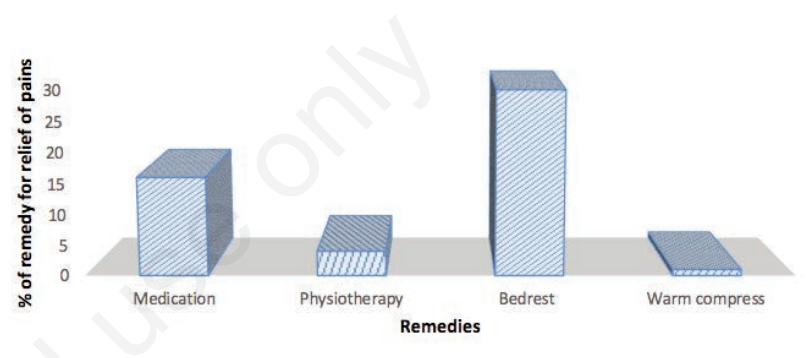

Figure 3. Remedy for Relief of Low Back/Pelvic Girdle Pains

Table 4. Cross-tabulation between the severity of the pains (evidenced by hospital admission) and their employment status.

\begin{tabular}{|c|c|c|c|c|}
\hline \multirow{2}{*}{\multicolumn{2}{|c|}{ Employment status }} & \multicolumn{2}{|c|}{$\begin{array}{l}\text { Have you ever been hospitalized due } \\
\text { to the severity of the pains? }\end{array}$} & \multirow[t]{2}{*}{ Total } \\
\hline & & Yes & No & \\
\hline \multirow[t]{2}{*}{ Employed } & Count & 15 & 2 & 17 \\
\hline & $\%$ of Total & 29.4 & 3.9 & 33.3 \\
\hline Unemployed & $\begin{array}{l}\text { Count } \\
\% \text { of Total }\end{array}$ & $\begin{array}{c}13 \\
25.5\end{array}$ & $\begin{array}{c}21 \\
41.2\end{array}$ & $\begin{array}{c}34 \\
66.7\end{array}$ \\
\hline Total & $\begin{array}{l}\text { Count } \\
\% \text { of Total }\end{array}$ & $\begin{array}{c}28 \\
54.9\end{array}$ & $\begin{array}{c}23 \\
45.1\end{array}$ & $\begin{array}{c}51 \\
100.0\end{array}$ \\
\hline
\end{tabular}

$\chi^{2}=11.443, \mathrm{P}=0.001$

Table 5. Cross-tabulation between the severity of the pains (evidenced by hospital admission) and family history of low back pains.

\begin{tabular}{|c|c|c|c|c|}
\hline \multicolumn{2}{|c|}{ Employment status } & \multicolumn{2}{|c|}{$\begin{array}{l}\text { Have you ever been hospitalized due } \\
\text { to the severity of the pains? }\end{array}$} & Tota \\
\hline Yes & $\begin{array}{l}\text { Count } \\
\% \text { of Total }\end{array}$ & $\begin{array}{c}12 \\
23.5\end{array}$ & $\begin{array}{c}7 \\
13.7\end{array}$ & $\begin{array}{c}19 \\
37.3\end{array}$ \\
\hline No & $\begin{array}{l}\text { Count } \\
\% \text { of Total }\end{array}$ & $\begin{array}{c}16 \\
31.4\end{array}$ & $\begin{array}{c}16 \\
31.4\end{array}$ & $\begin{array}{c}32 \\
62.7\end{array}$ \\
\hline Total & $\begin{array}{l}\text { Count } \\
\% \text { of Total }\end{array}$ & $\begin{array}{c}28 \\
54.9 \\
\end{array}$ & $\begin{array}{c}23 \\
45.1\end{array}$ & $\begin{array}{c}51 \\
100.0\end{array}$ \\
\hline
\end{tabular}

$\chi^{2}=0.834, \mathrm{P}=0.398$ 


\section{Discussion}

The mean age of patient with persistent back/pelvic girdle pains after pregnancy was $27.5 \pm 5.35$, this was similar to what was obtained by other studies (25-31yrs). ${ }^{4,11-14}$ The mean BMI of our study group was $28.0 \pm 5.36 \mathrm{Kg} / \mathrm{m}^{2}$. This is slightly higher than what was obtained in similar studies. ${ }^{11-13}$ This may be connected to the cultural preference to Overweight or high rate of multiparity, in most African society.

Back pain in most of our patients started from the second and third trimester. This is consistent with what has been reported in most literature. ${ }^{11,15}$ This has been attributed to the weight gain and hormonal changes that affect the ligaments of the back and pelvis that occur in the latter half of pregnancy. ${ }^{16}$

From our study, there was no significant evidence that CS increase the risk of post-partum Back pain. Other researchers had also reported similar conclusions. ${ }^{11,17}$ However; Mukkannavar et al. ${ }^{12}$ reported a high prevalence of post-partum back pain.

We also noted that previous history of trauma and vigorous exercise during pregnancy is a significant cause of admission during pregnancy.

Up to $47.1 \%$ of patient described their pain as radiating and most of them $(92.2 \%)$ have numbness or weakness. This is significantly higher than what was obtained by To and Wong ${ }^{11}$ and what the authors obtained in a similar topic among pregnant women. ${ }^{1}$ This was because the study population was only those with persistence of low back pain in this study. A significant number of patients $(51 \%)$ had their activities interfered with, by back/pelvic girdle pains and some had to be hospitalized. (51\% and 54\%). This is higher than the findings in other studies. ${ }^{1,8}$ About $39.2 \%$ of the respondent believed that their back pain is related to their activities. This is slightly lower than what was obtained among nonpregnant patient in studies done in Nigeria. ${ }^{18,19}$ There is a high correlation of back pain with activities like bending, lifting and prolong standing. ${ }^{18-21}$

The result indicated that there is generally low knowledge of back pain prevention and back education $(37.3 \%$ and $35.3 \%$ respectively). Knowledge of prevention of low back pains during pregnancy and postpartum include back and aerobic exercises, back education, mechanical support (corset), ergonomic interventions at workplace, and risk factor modifications (smoking cessation, weight loss etc). ${ }^{22,23}$ There was no statistically significant association between severity of the pains with most demographic feature like, Age, ethnicity, marital status, marriage setting, religion, parity and occupation $(\mathrm{P}<0.05)$.

Also, there was no statistically significant association between the severity of the pains and BMI $(\mathrm{p}<0.05)$. A similar finding has been reported by some workers, ${ }^{1,7}$ while some workers reported the contrary. ${ }^{24}$ There was also no significant association between the severity of the back pain with the trimester of pregnancy that the pain started ( $\mathrm{P}$ (Fischer's=) 0.932). There was statistically significant association between employment status and the severity of the pains $\left(\chi^{2}=11.443, \mathrm{P}=0.001\right)$. Those employed are more likely to have hospital admission due to severity of the pains. This may be connected to the sick role in the employed patients. Some perinatal demographic characteristics did not show significant role in pain severity. These are: gestational age at delivery, mode of delivery the duration of the last delivery, the weight of the baby in the last delivery. In our survey, antecedent history of trauma and engagement in strenuous exercise were not associated with severity of pain. Family history of low back pains was also not associated with the severity of the pains.

\section{Limitations}

It was a cross sectional survey. The researcher did not determine the incidence of persistence low back pain after pregnancy.

\section{Conclusions}

The survey showed that several factors such as increasing age, high parity and obesity that were found in patients with persistence of low back/pelvic girdle pains were not statistically associated with the severity of low back/pelvic girdle pains after delivery. However, employment status was statistically associated with severity of the pains $\left(\chi^{2}=11.443, \mathrm{P}=0.001\right)$.

The result indicated that there is generally low knowledge of back pain prevention and back education $(37.3 \%$ and $35.3 \%$ respectively). Concerning the means of relief for low back/pelvic girdle pains; bed rest was the most followed by medication and physiotherapy.

\section{Recommendations}

Knowledge of back pain prevention and back education should be incorporated into the routine health education given to women during antenatal care clinic and during postpartum visits. Further studies are required to determine the natural history of this pathology.

\section{References}

1. Usman M, Abubakar M, Muhammad S, et al. Low back pain in pregnant women attending antenatal clinic: The Aminu Kano teaching hospital experience. Ann Afr Med 2017;16.

2. Fung B, Kwong C, Ho E. Low back pain of women during pregnancy in the mountainous district of central Taiwan. Chung Hua I Hsueh Tsa Chih, Tappei 1993;51:103-6.

3. Ostgaard H, Andersson G, Wennergren M. The impact of low back pain and pelvic pain in pregnancy on the pregnancy outcome. Acta Obs Gynecol Scand 1991;70:21-4.

4. Gutke A, Östgaard H, Öberg B. Predicting persistent pregnancy-related low back pain. Spine (Phila Pa 1976) 2008;33:38693.

5. Albert H, Godskesen M, Korsholm L, Westergaard J. Risk factors in developing pregnancy-related pelvic girdle pain. Acta Obstet Gynecol Scand 2006;85:539-44.

6. Bergström C, Persson M, Mogren I. Pregnancy-related low back pain and pelvic girdle pain approximately 14 months after pregnancy - pain status, self-rated health and family situation. BMC Pregnancy Childbirth 2014;14:1-12.

7. Mogren I. Physical activity and persistent low back pain and pelvic pain post partum. BMC Public Health 2008;8:1-5.

8. Bergström C, Persson M, Mogren I. Sick leave and healthcare utilisation in women reporting pregnancy related low back pain and/or pelvic girdle pain at 14 months postpartum. Chiropr Man Ther 2016;24:1-11.

9. Pincus T, Burton A, Vogel S, Field A. A systematic review of psychological factors as predictors of chronicity/disability in prospective cohorts of low back pain. Spine (Phila Pa 1976) 2002;27:109-20.

10. Stuge B, Hilde G, Vollestad N. Physical therapy for pregnancy-related low back and pelvic pain: A systematic review. Acta Obstet Gynecol Scand 2003;82:983-90.

11. To W, Wong M. Factors associated with back pain symptoms 
in pregnancy and the persistence of pain 2 years after pregnancy. Acta Obstet Gynecol Scand 2003;82:1086-91.

12. Mukkannavar P, Desai B, Mohanty U, et al. Pelvic girdle pain after childbirth: The impact of mode of delivery. J Back Musculoskelet Rehabil 2013;26:281-90.

13. Abbasi S, Hamid M, Ahmed Z, Nawaz F. Prevalence of low back pain experienced after delivery with and without epidural analgesia: A non-randomised prospective direct and telephonic survey. Indian J Anaesth 2014;58:143-8.

14. Turgut F, Turgut M, Çetinşahin M. A prospective study of persistent back pain after pregnancy. Eur J Obstet Gynecol Reprod Biol 1998;80:45-8.

15. Olsson C, Nilsson-Wikmar, L Grooten W. Determinants for lumbopelvic pain 6 months postpartum. Disabil Rehabil 2012;34:416-22.

16. Cherni Y, Desseauve D, Decatoire A, et al. Evaluation of ligament laxity during pregnancy. J Gynecol Obstet Hum Reprod 2019;48:351-7.

17. Mogren I. Does caesarean section negatively influence the post-partum prognosis of low back pain and pelvic pain during pregnancy? Eur Spine J 2007;16:115-21.
18. Omokhodion F, Umar U, Ogunnowo B. Prevalence of low back pain among staff in a rural hospital in Nigeria. Occup Med (Chic Ill) 2000;50:107-10.

19. Sikiru, L Shmaila H. Prevalence and risk factors of low back pain among nurses in Africa: Nigerian and Ethiopian specialized hospitals survey study. East Afr J Public Heal 2009;6:225.

20. Al-Dajah S, Al-Daghdi A. Prevalence and Risk Factors of Low Back Pain Among Nurses in Sudayr Region. Eur Sci J 2013;9:198-205.

21. Karahan A, Kav S, Abbasoglu A, Dogan N. Low back pain: Prevalence and associated risk factors among hospital staff. J Adv Nurs 2009;65:516-24.

22. Lahad A, Malter A, Berg A, Deyo R. The effectiveness of four interventions for the prevention of low back pain (Structured abstract). JAMA 1994;272:1286-96.

23. Andersson GBJ. Epidemiology of low back pain. Acta Orthop Scand 1998;69:28-31.

24. Russell R, Dundas R, Reynolds F. Long term backache after childbirth: Prospective search for causative factors. Br Med J 1996;312:1384-8. 